\title{
Pengelolaan Budaya Inklusif Berbasis Nilai Belom Bahadat pada Huma Betang dan Transformasi Sosial Masyarakat Dayak Kalimantan Tengah
}

\author{
Dakir \\ IAIN Palangka Raya \\ dakir@iainpalangkaraya.ac.id
}

\begin{abstract}
This paper aims at analyzing the process of cultural values management of belom bahadat in creating an inclusive cultural life and social transformation in the Dayak community in buma betang using textual analysis method. The results reveal that the management model of cultural consensus of belom bahadat brings about changes in values, perspective and inclusive attitude and the formation of Dayak people's polarization into three models: the formation of inclusive attitude in understanding and accepting social, traditional, cultural and religious differences in family life, society and life of nation. This change strengthens the social integration between individuals and groups of different tribes, ethnics, cultural and religious groups in family life, society and nation. It also prevents the growth of radicalism and terrorism arising from religious figures, humanists and public figures in this modern age.

[Tulisan ini bertujuan menganalisis proses pengelolaan nilai budaya belom bahadat dalam menciptakan budaya kehidupan inklusif dan transformasi sosial pada masyarakat Dayak di buma betang dengan menggunakan metode analisis teks. Hasil studi menunjukan bahwa model pengelolaan konsensus budaya belom bahadat membawa perubahan nilai, cara pandang dan sikap inklusif dan terbentuknya polarisasi kehidupan masyarakat Dayak ke dalam tiga model yaitu terbentuknya sikap inklusif dalam memahami dan menerima perbedaan sosial, tradisi, budaya dan agama dalam kehidupan keluarga, kehidupan masyarakat dan kehidupan berbangsa. Perubahan ini memperkuat integrasi sosial antar individu dan kelompok yang berbeda suku, etnis, budaya dan agama dalam kehidupan keluarga, masyarakat dan bangsa serta mencegah tumbuhnya radikalisme dan terorisme yang
\end{abstract}


muncul dari kalangan tokoh-tokoh keagamaan, budayawan dan tokoh masyarakat di era modernisasi ini.]

Keywords: management, inclusive culture, value of balom bahadat, huma betang, social transformation.

\section{Pendahuluan}

Nilai budaya belom bahadat adalah sebuah kajian menarik dalam proses transformasi budaya kehidupan inklusif masyarakat Dayak melalui kehidupan keluarga betang. Sebagaimana dijelaskan Riwut bahwa nilai budaya belom bahadat atau kehidupan yang menghargai adat, tradisi, budaya, dan sistem kepercayaan setiap manusia di manapun berada merupakan tradisi kehidupan dari tokoh-tokoh adat Dayak untuk mengatur dan membangun kehidupan dalam keluarga betang yang anggotanya antara puluhan hingga ratusan keluarga dari beragam suku, etnis, agama, dan budaya. Mereka tinggal bersama dalam satu rumah di bawah bimbingan kepala adat betang untuk mencapai visi hidup rukun dan damai untuk kesejahteraan bersama. ${ }^{1}$

Hal senada juga dikatakan Ilon, bahwa nilai budaya belom bahadat atau kehidupan yang menghargai adat, tradisi, budaya, dan sistem kepercayaan setiap manusia di manapun berada adalah tradisi kehidupan leluhur suku Dayak yang telah dipraktikan sejak ratusan tahun silam untuk mengelola dan membangun ikatan persatuan, kekeluargaan, dan persaudaraan dalam kehidupan keluarga betang. Di dalam nilai budaya tersebut terkandung nilai kemanusiaan, kesetaraan, kekeluargaan, persaudaraan, dan kebebasan yang dapat mencairkan perbedaan setiap individu atas individu lain, bersatunya setiap individu dan kelompok yang berbeda suku, etnis, budaya, dan agama dalam mewujudkan kehidupan yang harmonis dan damai di lingkungan keluarga dan masyarakat. ${ }^{2}$

\footnotetext{
${ }^{1}$ Nilai Riwut, Kalimantan Membangun Alam dan Kebudayaan (Solo: NR Publishing, 2007), 36.

${ }^{2}$ Y. Nathan Ilon, Filsafat Huma Betang Suku Dayak Ngaju Kalimantan Tengah (Palangka Raya: PT. Sinar Bagawan Khatulistiwa, 1997), 16.
} 
Usop melihat dari aspek fisik bahwa huma atau rumah betang yang dibangun dengan konstruksi yang kokoh disebut bakota terdiri dari berbagai komponen yang berbeda tetapi saling menopang merupakan simbol yang di dalamnya terkandung makna saling menguatkan setiap individu dan komunitas yang berbeda suku, etnis, tradisi, budaya, dan agama serta membentuk cara pandang dan sikap masyarakat Dayak lebih inklusif dalam memahami perbedaan sosial, tradisi, budaya, dan agama dalam kehidupan keluarga betang dan masyarakat. ${ }^{3}$

Tradisi atau budaya kehidupan masyarakat suku Dayak dalam keluarga betang yang diikat dengan nilai budaya belom babadat atau kehidupan yang menghargai adat, tradisi, budaya, dan sistem kepercayaan setiap manusia yang dipraktekan oleh kepala adat bersama seluruh anggota keluarga betang dalam kehidupan sehari-hari telah mewujudkan pola kehidupan masyarakat Dayak pada umumnya lebih inklusif dalam memahami dan menerima perbedaan sosial, tradisi, budaya, dan agama dalam kehidupan keluarga dan masyarakat, tegas Maunati. ${ }^{4}$

Hal yang sama juga ditegaskan oleh Umbing, bahwa nilai budaya belom bahadat sebagai budaya luhur di dalamnya terkandung makna kehidupan yang senantiasa menghargai adat, tradisi, budaya, dan agama setiap manusia di manapun mereka hidup yang telah dipraktekan oleh kepala adat bersama anggota keluarga betang dalam kehidupan sehari-hari telah mencairkan, merekatkan perbedaan, dan terbentuknya sikap inklusif setiap kelompok yang berbeda suku, tradisi, budaya, dan agama yang saling menguatkan persatuan antar individu dan kelompok dan terciptanya wawasan kesatuan bangsa atau disebut utus di lingkungan keluarga dan masyarakat. ${ }^{5}$

Melihat analisis di atas, budaya belom bahadat atau kehidupan yang menghargai tradisi, adat, budaya, dan sistem kepercayaan setiap manusia

${ }^{3}$ Sidik Rahman Usop, “Akulturasi Nilai-Nilai Keislaman dan Budaya Dayak," Himmab: Jurnal Keagaman dan Kemasyarakatan 1, no. 2 (2016), 44.

${ }^{4}$ Yekti Maunati, Identitas Dayak: Komodifikasi dan Politik. Kebudayaan (Yogyakarta: Lkis, 2004), 63-64.

5Ibid., 56. 
di manapun berada, merupakan sebuah konsensus budaya adat yang sangat penting dalam studi pengelolaan budaya inklusif melalui kehidupan keluarga betang dan transformasi sosial masyarakat Dayak. Melalui studi ini akan menghasilkan model pengelolaan konsensus budaya belom bahadat yang membawa perubahan nilai, cara pandang dan sikap inklusif dalam memahami dan menerima perbedaan sosial, budaya, dan agama dalam kehidupan keluarga, masyarakat, dan kehidupan berbangsa. Model tersebut akan bermanfaat untuk memperkuat integrasi sosial antar individu dan kelompok yang berbeda suku, etnis, budaya, dan agama serta mencegah tumbuhnya radikalisme dan terorisme yang muncul dari kalangan tokoh keagamaan, budayawan, dan tokoh masyarakat di era modernisasi ini. Hal ini akan menjadi jelas jika dieksplorasi melalui proses model pengelolaan nilai budaya belom bahadat dalam kehidupan keluarga betang dalam menciptakan budaya kehidupan inklusif dan transformasi sosial masyarakat Dayak Kalimantan Tengah.

\section{Keberagaman Suku, Agama, dan Tempat Peribadatan di Kalimantan Tengah}

Berdasarkan data statistik Provinsi Kalimantan Tengah Tahun 2016 jumlah suku Dayak di seluruh wilayah Borneo sekitar 405 suku besar dan kecil. Suku Dayak Ngaju terdiri dari 4 golongan dan terbagi ke dalam 53 suku kecil. Dayak Ma'anyan terbagi ke dalam 8 suku kecil. Dayak Dusun terbagai ke dalam 8 suku kecil, dan Dayak Lawangan terbagi ke dalam 21 suku kecil. Selain itu, juga terdapat suku Dayak Ot seperti suku Ot Panyawung, Ot Siauw, Ot Mondai, Ot Pari, dan Ot Olong-olong yang tinggal di pegunungan hulu sungai Kahayan, Barito, Rungan, Manuhing, Katingan, dan Kapuas yang kehidupanya masih sangat sederhana. ${ }^{6}$

Jumlah persentase penduduk Kalimantan Tengah terbesar adalah suku Dayak sekitar 50,43 \%. Suku Banjar 23,03\%, suku Jawa 21,43 \%, suku Madura 2,09\%, suku Bali, NTT, Batak, Bugis, Manado, dan lainya 3,03\%. Bahasa yang digunakan sangat beragam, bahasa Dayak Ngaju,

${ }^{6}$ BPS Provinsi Kalimantan Tengah, Penduduk Kalimantan Tengah Tabun 2016 (Palangka Raya: BPS, 2016), 16. 
Dayak Ma'nyan, Dayak Dusun, Dayak Katingan, dan Dayak Bakumpai. Hal ini menujukan bahwa Kalimantan Tengah dengan luas wilayah $153.828 \mathrm{~km}^{2}$ dengan perbandingan 1,5 kali pulau Jawa dan jumlah penduduk 3,4 juta jiwa memiliki potensi pluralitas suku, etnis, agama, dan budaya yang cukup tinggi. ${ }^{7}$

Adapun jumlah penduduk yang beragama Islam sekitar 1.692.132 jiwa, agama Kristen Protestan 338.077 jiwa, Katolik 61.747 jiwa, Hindu 187.118 jiwa, Budha 5.343 jiwa, dan Khong $\mathrm{Hu} \mathrm{Cu} 96$ jiwa. Dalam menjalankan ibadah dan perayaan hari besar keagamaan dan interaksi sosial setiap penganut agama sangat harmonis. Demikian juga dalam pendirian dan pembangunan tempat peribadatan. Jumlah tempat ibadah masing-masing agama di Kalimantan Tengah menunjukan tren yang meningkat hingga tahun 2016, jumlah Masjid dan Mushalla sekitar 3.571 buah, Gereja Protestan 1.692 buah, Gereja Katolik 198 buah, Pura 77 buah, Vihara 12 buah dan Klenteng 4 buah. Kondisi masing-masing tempat peribadatan terpelihara dengan baik. ${ }^{8}$

\section{Pengertian Budaya Belom Bahadat dan Huma Betang}

Ilon mendefinisikan budaya belom babadat merupakan nilai luhur, warisan dari para leluhur tokoh adat Dayak sebagai prinsip kehidupan masyarakat suku Dayak yang senantiasa menghargai adat, tradisi, budaya, dan sistem kepercayaan setiap manusia di manapun berada, serta menghormati sesama, alam semesta, dan budaya setempat yang di dalamnya terkandung pengakuan derajat kemanusiaan dan seluruh keunikanya secara utuh. Nilai tersebut juga menjadi etika bersama yang telah disepakati oleh seluruh kepala adat Dayak dalam Rapat Damai Tumbang Anoi tahun 1894 dan ditetapkan dalam hukum adat Dayak yang harus ditaati oleh seluruh masyarakat suku Dayak untuk mencapai kehendak umum yaitu kesetaraan, kedalian, kebersamaan, kedamaian, dan harmonisasi dengan Tuhan, sesama manusia, dan alam. ${ }^{9}$

${ }^{7}$ Ibid.,19.

${ }^{8}$ Ibid., 21.

${ }^{9}$ Ibid., 26. 
Sementara Iper mendefinisikan rumah betang adalah sebuah rumah yang dapat menampung antara puluhan sampai ratusan anggota keluarga yang beragam suku, etnis, tradisi, budaya, agama, dan mereka tinggal dalam satu atap di bawah bimbingan kepala adat betang. ${ }^{10}$

Menurut Maunati, buma betang adalah sebuah rumah panjang yang didirikan oleh kepala adat bersama penduduk dari berbagai suku, etnis, tradisi, budaya, agama, dan mereka tinggal bersama dalam satu keluarga besar untuk membangun kehidupan bersama yang dilandasi nilai budaya belom bahadat, yaitu kehidupan yang menghargai tradisi, budaya, dan sistem kepercayaan setiap manusia dan alam semesta di manapun mereka hidup untuk mencapai visi hidup rukun dan damai untuk kesejahteraan bersama. $^{11}$

Dalam makna lebih luas, Sulang menegaskan bahawa rumah betang merupakan pusat kebudayaan, pusat kehidupan sosial, pusat religius, pusat pendidikan, dan jantung struktur sosial kehidupan masyarakat suku Dayak, di mana setiap kehidupan individu diikat dengan nilai budaya belom bahadat atau kehidupan yang menghargai adat, tradisi, budaya, dan sistem kepercayaan setiap manusia di manapun berada yang diatur dalam hukum adat untuk mencapai hidup rukun dan damai untuk kesejahteraan bersama. ${ }^{12}$

\section{Nilai Budaya Inklusif dalam Kehidupan Keluarga Huma Betang}

Sebagaimana dijelaskan Riwut bahwa kehidupan masyarakat suku Dayak dalam keluarga betang senantiasa berpegang teguh pada nilai budaya adat yang disebut belom bahadat atau menghargai adat, tradisi, budaya, dan sistem kepercayaan setiap manusia di manapun mereka berada. Nilai tersebut berakar dari tradisi kehidupan para leluhur suku Dayak yang muncul sejak tahun 1883 atau bahkan jauh sebelumnya yang

\footnotetext{
${ }^{10}$ Dunis Iper, Kosa Kata Bahasa Dayak Ngaju-Indonesia (Palangka Raya: PT Bengawan Khatulistiwa, 2009), 88.

${ }^{11}$ Ibid., 71.

${ }^{12}$ Kusni Sulang, Budaya Dayak, Permasalaban, dan Alternatifnya: Berdiri di Kampung Halaman Memandang Tanah Air Merangkul Dunia (Malang: Bayumedia, 2011), 119.
} 
diwariskan kepada setiap generasi suku Dayak melalui kehidupan rumah betang untuk mencapai visi hidup rukun dan damai untuk kesejahteraan bersama. ${ }^{13}$

Nilai budaya belom bahadat yang berarti menghargai adat, tradisi, budaya, dan sistem kepercayaan setiap manusia di manapun berada, di dalamnya terkandung nilai-nili inklusif. Pertama, pengakuan derajat setiap manusia dan seluruh keunikanya secara utuh. Nilai tersebut menjadi landasan kehidupan masyarakat suku Dayak untuk membangun kehidupan yang senantiasa menghargai adat, tradisi, budaya, dan agama setiap manusia, alam semesta, dan budaya setempat, di mana bumi dipijak di situ langit dijunjung. Nilai tersebut juga menjadi etika bersama yang diatur dalam hukum adat Dayak yang harus ditaati oleh seluruh anggota keluarga betang dan masyarakat untuk mencapai kehendak umum, yaitu: kesetaraan, kedalian, kebersamaan, kedamaian, dan harmonisasi dengan Tuhan, sesama manusia, dan alam. Kedua, handep atau gotong royong, kekeluargaan, dan persaudaraan adalah tradisi atau budaya kehidupan masyarakat suku Dayak yang paling dominan dalam kehidupan keluarga betang. Nilai tersebut menjadi pemersatu seluruh anggota keluarga betang yang menyadarkan bahwa perbedaan suku, etnis, ras, tradisi, budaya, dan sistem kepercayaan tetap bersatu dan berjuang bersama dalam menghadapi tantangan dari luar. Perbedaan kompetensi setiap manusia sebagai kunci perekat untuk meniadakan perbedaan dalam kehidupan bersama di rumah betang. Perbedaan manusia dianggap sebagai karakter khas setiap manusia untuk saling melengkapi sebagai satu keluarga dalam ikatan persaudaraan keluarga betang dan komunitas masyarakat suku Dayak. Ketiga, panganraun atau solideritas, kebersamaan, persaudaraan, dan gotong royong merupakan tradisi atau budaya yang menjadi landasan dasar kehidupan masyarakat suku Dayak dan keluarga betang. Di dalam budaya tersebut terkandung makna tidak ada penindasan

${ }^{13}$ Ibid., 39. 
dan keserakahan dalam kehidupan di lingkungan keluarga dan masyarakat. ${ }^{14}$

Lewis juga menjelaskan bahwa nilai budaya belom bahadat yang dipraktekan oleh seluruh anggota keluarga betang di bawah bimbingan kepala adat dalam kehidupan sehari-hari telah melahirkan nilai-nilai inklusif lainya, seperti bandep atau panganraun atau gotong royong, kekeluargaan dan persaudaraan, saling membantu di antara sesama keluarga dalam setiap kegiatan, dan hapakat basara atau musyawarah mufakat dalam menyelesaikan masalah sosial dan kemanusiaan. Nilainilai budaya inklusif ini telah dipraktikan oleh seluruh tokoh-kepala adat Dayak bersama masyarakatnya sejak ratusan tahun silam untuk membangun kehidupan yang senantiasa lebih mengutamakan persaudaraan sebagai perekat untuk menyatukan seluruh anggota keluarga betang yang berbeda suku, etnis, tradisi, budaya, dan agama. Misalnya dalam kerjasama dibidang pertanian atau berkebun, mulai dari membuka lahan pertanian, manugal atau menaburkan benih hingga panen dilakukan dengan gotong royong. Selain itu, jika dalam satu penghuni betang ada yang sakit, maka seluruh penghuni rumah betang akan musyawarah yang dipimpin kepala adat betang. Demikian juga jika ada serangan musuh yang mengganggu anggota keluarga betang, maka seluruh anggota keluarga betang akan melakukan perlawanan bersama. Pola kehidupan masyarakat suku Dayak yang dilandasi nilai budaya inklusif ini telah melahirkan semboyan populer pada masyarakat suku Dayak yang disebut tuntang harati atau pintar dan berbudi dan isen mulang atau pantang rnundur. Karena itu, nilai budaya belum bahadat merupakan gambaran budaya luhur masyarakat suku Dayak secara utuh untuk mencapai visi hidup rukun dan damai untuk kesejahteraan bersama. ${ }^{15}$

Lebih lanjut Lewis menjelaskan bahwa hapakat basara atau musyawarah mufakat adalah salah satu tradisi atau budaya kehidupan

\footnotetext{
${ }^{14}$ Ibid., 54.

${ }^{15}$ Lewis KDR, "Interaksi Sosial dalam Keluarga Betang," dalam Falsafah Hidup Budaya Huma Betang dalam Membangun Kerukunan Hidup Umat Beragama di Kota Palangka Raya, eds. Muhammad dan Abubakar (Malang: Aditya Media, 2010), 52.
} 
masyarakat suku Dayak dalam menyelesaikan masalah lebih mengutamakan musyawarah mufakat, kekeluargaan, dan perdamaian, di mana prinsip kolektif tidak menegasikan kedudukan atau hak individu. Keduanya sejajar meskipun ketika kepentingan umum menuntut diutamakan, maka individu secara sadar melepaskan kepentingannya. Artinya, kepentingan individu dan kolektif teranyam baik. Prinsip ini manjadi budaya kehidupan masyarakat suku Dayak tidak hanya dalam komunitas keluarga betang tetapi juga dalam kehidupan bermasyarakat. Hapakat basara dalam budaya kehidupan keluarga betang disebut prinsip demokrasi. Artinya, tradisi atau budaya kehidupan masyarakat suku Dayak dalam keluarga betang lebih mengutamakan keadilan dan menolak kesewenang-wenangan. Nilai inklusif ini menjadi landasan yang senantiasa ditegakan oleh kepala adat betang bersama seluruh anggota keluarga untuk menyelesaikan masalah sosial di lingkungan keluarga betang dan dalam kehidupan masyarakat. Melalui kehidupan yang demokratis ini, hak asasi setiap manusia mendapat jaminan karena tertuang dalam kepentingan umum. ${ }^{16}$

Dalam hal ini, Usop juga menjelaskan bahwa prinsip hapakat basara yang senantiasa ditegakan oleh kepala adat dalam kehidupan keluarga betang dan masyarakat adalah untuk mengatur pluralitas kehidupan yang demokratis agar mereka dapat hidup saling menghormati dalam suasana damai dan harmonis. Dalam budaya kehidupan keluarga betang dan masyarakat suku Dayak, setiap manusia harus saling menolong dan saling menghormati tanpa melihat perbedaan suku, etnik, ras, tradisi, budaya, dan agama di wilayah mereka hidup. Dengan kata lain, dalam kehidupan keluarga betang dan masyarakat suku Dayak pada dasarnya tidak mengenal tradisi atau budaya feodalisme. Bagi mereka yang berlaku adalah prinsip kesetaraan derajat di hadapan Tuhan Yang Maha Esa atau disebut Ranying Hatalla Langit. Laki-laki dan perempuan memiliki tanggungjawab yang sama dalam keluarga dan masyarakat. Demikian pula dalam kehidupan keluarga betang, seluruh anggota keluarga yang berbeda suku,

${ }^{16}$ Ibid., 63. 
etnis, tradisi, budaya, dan agama memiliki kedudukan yang sama. Spirit kesetaraan ini mengikat seluruh anggota keluarga betang, di mana kedamaian, keharmonisan, kesetaraan, dan keadilan menjadi tanggungjawab bersama. ${ }^{17}$

\section{Proses Pengelolaan Nilai Budaya Belom Bahadat dalam} Menciptakan Budaya Kehidupan Inklusif dan Transformasi Sosial pada Masyarakat Dayak Kalimantan Tengah

Soemardjan mendefinisikan transformasi sosial adalah semua perubahan yang terjadi pada lembaga-lembaga kemasyarakatan dalam suatu masyarakat di mana perubahan tersebut mempengaruhi sistem sosialnya yang mencakup nilai, sikap, dan pola tingkah laku di antara kelompok-kelompok masyarakat. ${ }^{18}$ Davis menjelaskan bahwa suggests that social transformation is changes that occurred in the structure and functioning of a society. ${ }^{19}$ Sementara Moreover menyatakan, metton asserts that social transformation is changes in social relation or changes in the sustainability of social relations. ${ }^{20}$ Merujuk dari definisi ini, esensi dari transformasi sosial adalah perubahan sosial yang terjadi pada masyarakat Dayak yang diindikasikan dengan perubahan nilai, cara pandang, dan sikap inklusif dalam interaksi dan komunikasi antar individu dan kelompok yang berbeda suku, etnis, ras, tradisi, budaya, dan agama dalam lingkungan keluarga dan masyarakat.

Tidak diragukan lagi bahwa model pengelolaan konsensus budaya belom bahadat telah membawa perubahan polarisasi kehidupan sosial dan keagamaan masyarakat Dayak, yaitu cara pandang dan sikap inklusif dalam memahami dan menerima perbedaan sosial, tradisi, budaya, dan

\footnotetext{
${ }^{17}$ Wahidin Usop, "Memahami Budaya Betang dalam Perspektif Integrasi sosial" (Makalah disampaikan pada acara dialog Internasional di Aula Universitas Negeri Palangka Raya tentang Budaya Dayak dan Melayu, Palangka Raya, 1 November 2014), 4.

${ }^{18}$ Selo Soemardjan, Setangkai Bunga Sosiologi (Jakarta: Universitas Indonesia Press, 1974), 23.

${ }^{19}$ Kingsley Davis, Human Society (New York: Mc Graw-Hill, 1948), 309.

${ }^{20}$ Robert K. Metton, Social Structure and Science (Chicago: The University of Chicago Press, 1994), 106.
} 
agama dalam kehidupan keluarga, masyarakat, dan berbangsa. Perubahan ini memperkuat integrasi sosial antar individu dan kelompok yang berbeda suku, etnis, budaya, dan agama dalam kehidupan keluarga, masyarakat, dan bangsa serta mencegah tumbuhnya radikalisme dan terorisme yang muncul dari kalangan tokoh-tokoh keagamaan dan tokoh masyarakat di era modernisasi ini.

Legitimasi konsensus tokoh adat dan pemerintah daerah pemberlakuan nilai budaya belom bahadat sebagai prinsip dasar kehidupan masyarakat Dayak. Model konsensus ini telah mendorong setiap kelompok tokoh adat dan agama yang berbeda suku, etnis, budaya, dan agama berpegang pada prinsip budaya belom bahadat telah membawa perubahan cara pandang dan sikap inklusif dalam menyikapi perbedaan sosial, budaya, dan agama. Sebagaimana ditegaskan Usop, bahwa nilai budaya belom bahadat sebagai pedoman bersama bagi kehidupan seluruh masyarakat suku Dayak adalah menghormati adat, tradisi, budaya, dan sistem kepercayaan setiap manusia di manapun mereka hidup merupakan hasil kesepakatan dari 152 kepala dan tokoh adat dari 152 suku yang hadir dalam Rapat Damai Tumbang Anoi pada tanggal 22 Mei-25 Juli 1894 yang diatur dalam hukum adat dan diperkuat dalam Peraturan Pemerintah Daerah Nomor 16 Tahun 2008. Nilai budaya ini telah mendorong semakin menguatnya pemahaman masyarakat Dayak terhadap nilai budaya belom bahadat, terbukti mereka sangat menghormati perbedaan-perbedaan nyata dalam kehidupan keluarga dan masyarakat. ${ }^{21}$ Dengan kata lain, legitimasi konsensus budaya belom bahadat menjadi landasan pemerintah daerah, tokoh-tokoh adat, dan tokoh agama-agama dalam membina persatuan dalam kehidupan sosial, budaya, agama, dan bangsa.

Model ini telah memperkuat ikatan persatuan kehidupan antar umat beragama, wawasan kesatuan bangsa, meningkatnya pemahaman dan sikap inklusif antar umat beragama, dan integrasi sosial yang saling

${ }^{21}$ Abdurrahman Sidik Usop, Sejarah Kabupaten Kapuas (Palangka Raya: PT. Sinar Bagawan Khatulistiwa, 1994), 28. 
menguatkan pada setiap kelompok agama. Hal ini tersirat dalam penjelasan Usop bahwa nilai budaya belom bahadat yang dipraktikan dalam kehidupan sehari-hari oleh kepala adat bersama seluruh anggota keluarga betang dan masyarakat telah menunjukan kehidupan komunitas, tokohtokoh agama, dan pemerintah yang berbeda etnis, ras, agama, dan budaya untuk saling menguatkan satu sama lain dan terciptanya interaksi dan komunikasi antar individu dan kelompok dalam kehidupan keluarga dan masyarakat Dayak lebih inklusif dalam memahami dan menerima semua perbedaan. Hal yang dapat dilihat misalnya setiap malam peringatan hari kemerdekaan Republik Indonesia, pemerintah Kalimantan Tengah mengadakan resepsi dengan mengundang seluruh tokoh agama Kaharingan, Islam, Kristen, Budha, dan Khong $\mathrm{Hu} \mathrm{Cu}$ untuk memimpin doa bersama agar bangsa Indonesia tetap utuh menjadi negara kesatuan Republik Indoneisa dan segera keluar dari krisis ekonomi, politik, sosial dan budaya, serta menjadi negara yang damai, sejahtera, berkeadilan, bermoralitas, dan beradab. Ini merupakan bukti semakin menguatnya pemahaman nilai budaya belom bahadat dalam wawasan kesatuan kebangsaan dari masyarakat suku Dayak. ${ }^{22}$

Sementara itu, transmisi dan internalisasi budaya belom bahadat setiap kelompok etnis, budaya, dan agama dalam institusi keluarga betang membawa perubahan nilai, cara pandang dan sikap inklusif serta menguatkanya persatuan setiap kelompok yang berbeda suku, etnis, budaya, dan agama dalam lingkungan keluarga betang dan masyarakat. Hal ini sebagaimana dinyatakan oleh Riwut bahwa internalisasi budaya belom bahadat atau kehidupan yang menghargai adat, tradisi, budaya, dan sistem kepercayaan setiap manusia di manapun mereka hidup dalam kehidupan sehari-hari di rumah betang telah mewujudkan sikap setiap kelompok yang berbeda suku, etnis, budaya, dan agama untuk saling memahami, menerima, dan menghargai perbedaan. Mereka hidup rukun dan damai. Ini suatu keunikan budaya kehidupan masyarakat Dayak yang senantiasa berpegang pada prinsip belom bahadat. Nilai luhur ini merupakan tradisi

${ }^{22}$ KMA Usop, "Sistem Religi Masyarakat Dayak," Himmah: Jurnal Ilmiah Keagamaan dan Kemasyarakatan 2, no. 23 (2001), 19. 
atau budaya kehidupan dari tokoh-tokoh Dayak ratusan tahun silam dalam membangun kehidupan bersama dengan berbagai suku Dayak lain yang berbeda etnis, tradisi, budaya, dan sistem kepercayaan, di mana mereka tinggal bersama dalam satu rumah betang dengan rukun, damai, dan harmonis. ${ }^{23}$

Siyok dan Tiwi memperkuat dalam penjelasanya bahwa nilai budaya belom bahadat atau kehidupan yang menghargai adat, tradisi, budaya, dan sistem kepercayaan setiap manusia di manapun berada, yang dipraktikan dalam kehidupan sehari-hari oleh kepala adat bersama seluruh anggota keluarga betang telah membentuk pola kehidupan keluarga betang dan masyarakat Dayak lebih inklusif dalam memahami dan menerima perbedaan sosial, adat, tradisi, budaya, dan agama. Dalam satu keluarga suku Dayak banyak ditemukan kakeknya beragama Hindu Kaharingan, suaminya suku Dayak beragama Kristen dan isterinya suku Jawa sebagai Muslim, anak-anaknya beragama Kristen dan Muslim tetapi kondisi kehidupan keluarga mereka damai dan penuh toleransi dalam menjalankan ibadah sesuai kepercayaan masing-masing. ${ }^{24}$

Relevan dengan penegasan di atas, Muhammad menyatakan bahwa komunitas keluarga betang pada awalnya adalah penduduk asli suku Dayak yang memiliki sistem kepercayaan agama Hindu Kaharingan, sebuah kepercayaan yang bersumber dari mitologi yang diyakini oleh masingmasing sub etnik Dayak. Mitologi tersebut, tertuang dalam mitos-mitos yang dianggap memiliki kebenaran mutlak disebut penaturan tamparan latuh handai. Mitos-mitos tersebut juga merupakan kombinasi dari mitos kosmologi, mitos asal usul, mitos tentang mahluk Ilahi, dan mitos androgini yang dibukukan sebagai kitab suci agama Kaharingan. Umat Kaharingan percaya adanya penguasa tertinggi langit dan bumi yang mereka sebut Ranying Hatala Langit. Dalam perkembanganya, sekitar 20\% dari mereka memegang teguh kepercayaan leluhurnya yang disebut agama Kaharingan. Selain itu, masyarakat Dayak juga menganut agama

${ }^{23}$ Ibid., 103.

${ }^{24}$ Demianus Siyok dan Tiwi, Etika Mutiara Isen Mulang: Memahami Bumi dan Manusia (Palangka Raya: PT. Sinar Bagawan Khatulistiwa, 2014), 213. 
lain, seperti Islam sekitar 1.692.132 jiwa, agama Kristen Protestan 338.077 jiwa, Katolik 61.747 jiwa, Hindu 187.118 jiwa, Budha 5.343 jiwa, dan Khong $\mathrm{Hu} \mathrm{Cu} 96$ jiwa. Meski demikian, mereka mampu membina kehidupan antar umat beragama secara harmonis, rukun, dan damai, karena kehidupan setiap individu dan kelompok yang berbeda suku, etnis, dan budaya masing-masing diikat dengan konsensus belom bahadat atau kehidupan yang senantiasa menghargai adat, tradisi, budaya, dan sistem kepercayaan setiap manusia di manapun mereka hidup. ${ }^{25}$

Lebih dalam Usop menyatakan bahwa agama Hindu masuk ke provinsi Kalimantan Tengah tahun 400 SM, mengajarkan setiap manusia memiliki kesamaan derajat di hadapan Hatalla Langit, agama Islam pada abad ke 16, mengajarkan kedamaaian dan kesetaraan di hadapan Tuhan Yang Maha Esa, agama Kristen protestan abad ke 19 (1835), dan agama Katholik tahun 1894 mengajarkan cinta kasih. Perbedaan agama ini diikat dengan budaya belom bahadat atau kehidupan yang senantiasa menghargai adat, tradisi, budaya, dan sistem kepercayaan setiap manusia di manapun berada yang diwariskan kepada setiap generasi melalui bimbingan kepala adat dalam kehidupan sehari-hari di huma betang. Dalam kurun waktu yang panjang, hal itu telah mewujudkan nilai dan sikap masyarakat Dayak pada umumnya lebih inklusif dalam memahami dan menerima perbedaan sosial, tradisi, budaya, dan agama dalam kehidupan keluarga dan masyarakat. Mereka saling menghargai satu sama lain dan saling memotivasi dalam melaksanakan ibadah sesuai dengan keyakinan dan kepercayaan masing-masing. ${ }^{26 .}$

Legitimasi pemberlakuan budaya belom bahadat sebagai prinsip kesetaraan kehidupan sosial, gender, budaya, dan agama dalam keluarga betang dan masyarakat telah membawa perubahan kesetaraan kehidupan sosial dan sikap toleransi yang tinggi dari setiap anggota keluarga betang dan masyarakat suku Dayak yang berbeda etnis, tradisi, budaya, dan

\footnotetext{
${ }^{25}$ Muhammad, Falsafah Hidup Budaya Huma Betang dan Integrasi Sosial di Kalimantan Tengah (Malang: Aditya Media, 2014), 63.

${ }^{26} \mathrm{Ibid} ., 26$.
} 
agama. Sebagaimana ditegaskan Ahmad bahwa bentuk perubahan sosial dari nilai budaya belom bahadat atau kehidupan yang menghargai adat, tradisi, budaya, dan sistem kepercayaan setiap manusia yang dipraktikan oleh seluruh anggota keluarga betang dan masyarakat suku Dayak melalui bimingan kepala adat betang dalam kehidupan sehari-hari, telah berkembang manjadi budaya hapakat (saling membantu, solideritas, dan persaudaraan) dan budaya hapakat basara (musyawarah mufakat dalam menyelesaikan masalah sosial dan keagamaan).

Selain itu, dalam kehidupan keluarga betang dan masyarakat suku Dayak tidak berlaku strata sosial antara satu dengan lainnya sebagaimana dikenal dalam masyarakat lain pada umumnya, seperti karaeng dalam budaya Makasar, andi dalam budaya Bugis, raden dalam budaya Jawa. Masyarakat Dayak tidak mengenal istilah-istilah teknis yang mengarah pada status sosial yang berbeda antara satu dengan lainnya. Hal ini menunjukan nilai persamaan derajat kemanusiaan, kesetaraan, kekerabatan, persaudaraan, kedamaian, dan keharmoniasan. Di rumah betang terdapat berbagai ragam kepercayaan. Seluruh keluarga betang terbiasa hidup rukun, damai, dan harmonis. Tidak pernah terjadi perselisihan, kerena tingkat kekeluargaan atau kekerabatan sangat tinggi.

Di saat ada perayaan agama Islam seperti Idul Fitri, warga agama lain di rumah itu ikut pula merayakannya, begitu juga saat Natal atau perayaan agama Kaharingan, warga Muslim juga ikut merayakannya. Suasana seperti itu sudah terlihat sejak munculnya kehidupan keluarga betang sekitar tahun 1883-an, bahkan jauh sebelumnya. Contoh lain misalnya dalam hal gender, perempuan di mata masyarakat Dayak memiliki martabat yang tinggi, dihargai, dihormati, dan dilindungi oleh laki-laki. Nilai budaya belom bahadat telah menempatkan perempuan pada posisi yang menguntungkan. Ini dimaksudkan agar kaum perempuan Dayak tidak mudah dipermainkan oleh laki-laki Dayak dan luar Dayak. Apabila seorang laki-laki, mislanya dalam kasus perkawinan tidak disetujui keluarga perempuan, kemudian ia membawa lari perempuan Dayak dan menodainya, maka dia akan dikenakan jïpen atau denda. 
Hal ini menunjukan dalam kehidupan keluarga betang dan masyarakat suku Dayak telah menempatkan perempuan sejajar dengan laki-laki, yang berbeda hanya peranan dan fungsi dari keduanya. Mereka memiliki hak yang sama dalam tugas kemasyarakatan dan rumah tangga. Laki-laki dan perempuan dalam budaya kehidupan keluarga betang harus hidup dalam ikatan solidaritas, kesetiaan, dan kesetaraan. Apabila dikaitkan dengan jïpen yang dibebankan kepada laki-laki, maka ia mengandung nilai penghormatan atas martabat perempuan. ${ }^{27}$

Dalam hal kesetaraan laki-laki dan perempuan dalam kehidupan keluarga betang dan masyarakat Dayak dapat dilihat dalam ikatan tanda cinta dan perkawinan. Dalam budaya Dayak tidak mengenal perceraian maupun poligami. ${ }^{28}$

Legitimasi konsensus budaya belom bahadat sebagai landasan kebijakan pengembangan lembaga pendidikan, pusat kajian sosial, budaya, keagamaan, dan tempat peribadatan setiap kelompok agama dan budaya diberlakukan secara adil. Model ini meningkatkan pengetahuan, pemahaman, dan sikap kehidupan yang menghargai perbedaan sosial, tradisi, budaya, dan agama setiap individu dan kelompok serta terciptanya kehidupan sosial dan keagamaan yang harmonis dan damai.

Nilai budaya belom bahadat atau budaya kehidupan yang menghargai adat, tradisi, budaya, dan sistem kepercayaan setiap manusia di manapun berada diperkuat dalam Peraturan Pemerintah Daerah Nomor 16 Tahun 2008 dalam bentuk Kelembagaan Adat Dayak Kalimantan Tengah. Selanjutnya ditindaklanjuti dengan kebijakan pemerintah Provinsi Kalimantan Tengah melalui pembangunan dan pendirian institusi keagamaan seperti Pusat Studi Islam atau Islamic Centre, Pusat Studi Agama Kristen, dan Pusat Studi Agama Kaharingan untuk meningkatkan kualitas pendidikan keagamaan, keilmuan, dan kebudayaan serta

\footnotetext{
${ }^{27}$ Ibid., 67.

${ }^{28}$ Paulus Alfon, "Kedudukan Laki-laki dan Perempuan dalam Keluarga Betang," dalam Falsafah Hidup Budaya Huma Betang dalam Membangun Kerukunan Hidupn Umat Beragama di Kota Palangka Raya, eds. Muhammad dan Abubakar (Malang: Aditya Media, 2010), 51.
} 
pembinaan kehidupan sosial keagamaan bagi seluruh pemeluk agama. Kebijakan ini dapat meningkatkan kualitas hidup mereka yang senantiasa menghargai perbedaan sosial, adat, tradisi, budaya, dan agama sesuai dengan visi hidup masyarakat suku Dayak, yaitu belum penyang binje simpei atau hidup rukun dan damai untuk kesejahteraan bersama atas dasar kemanusiaan. ${ }^{29}$

Isa, salah satu ulama dan cendikiawan Muslim Kalimantan Tengah menegaskan bahwa pemerintah Kalimantan Tengah telah menerapkan kebijakan pembangunan tempat peribadatan secara adil dan merata, di mana pembangunan tempat-tempat peribadatan Muslim dan Kristen dilaksanakan secara terpadu, masjid dan gereja letaknya selalu berdampingan. Kebijakan ini telah direncanakan pemerintah daerah sejak tahun 1980-an, bahkan jauh sebelumnya. Ini adalah realisasi dari konsensus budaya belom bahadat dalam mewujudkan kebebasan setiap manusia dalam menjalankan ibadat sesuai kepercayan masing-masing, pembudayaan sikap toleransi untuk memperkuat kerukunan antar umat beragama, harmonisasi kehidupan antar umat beragama dan persatuan antar umat beragama, di mana setiap pemeluk agaman Islam, Kristen, Hindu Kaharingan, Budha, dan Konghuncu semakin arif dan bijaksana dalam memahami dan menyikapi perbedaan sosial, budaya, dan agama. Kebijakan ini berdampak semakin menguatnya sikap toleransi dan kedamaian dalam kehidupan antar umat bergama dalam lingkungan keluarga, masyarakat, dan bangsa. Hal yang dapat dilihat misalnya pada saat umat Islam merayakan hari-hari besar keagamaan, seperti hari raya Idul Fitri atau Idul Adha yang bertepatan pada hari minggu. Dalam hal ini, kegiatan ibadah umat Kristen di gereja oleh pendeta diliburkan atau diganti pada sore harinya. Ini merupakan contoh pemahaman dan sikap yang berpegang pada nilai belom bahadat atau sikap inklusif dan toleran

${ }^{29}$ Ibid., 29. 
dari tokoh-tokoh Kristen dan masyarakat suku Dayak dalam memahami dan menerima perbedaan keyakinan. ${ }^{30}$

Pelembagaan budaya belom bahadat melalui lembaga musyawarah adat untuk menyelesaikan konflik sosial dan keagamaan dengan prinsip hapakat basara atau musyawarah mufakat, kekelurgaan, dan perdamaian membawa perubahan terciptanya kesetaraan, kebebasan, kesadilan, perdamaian, dan persatuan kehidupan sosial dan keagamaan yang saling menguatkan antar individu dan kelompok yang berbeda suku, etnis, budaya, dan agama dalam keluarga betanag dan masyarakat Dayak.

Menurut Usop, Ketua Presidium Lembaga Musyawarah Masyarakat Dayak Kalimantan Tengah, secara historis budaya belom bahadat dan hapakat basara atau pengambilan keputusan berdasarkan musyawarah mufakat adalah salah satu bagian dari budaya belom babadat yang telah dipraktikan oleh para tokoh-tokoh nenek moyang mereka selama satu abad, sejak rapat damai Tumbang Anoi tahun 1894. Rapat damai ini mengandung beberapa nilai. Pertama, nilai damai, yaitu kehidupan yang menolak cara-cara kekerasan dalam menyelesaikan masalah dan menekankan pada prinsip hapakat basara atau musyawarah mufakat. Kedua, kebebasan beragama, yaitu semua orang memiliki kepercayaan terhadap Tuhan walaupun berbeda nama dan peribadatan. Permasalahan konflik sosial bagi masyarakat suku Dayak yang multireligius, multietnik, dan multibudaya diselesaikan melalui pendekatan bapakat basara. Ketiga, menjunjung tinggi nilai kemanusiaan dan nilai kebangsaan. Keempat, mengutamakan kesejahteraan bersama yang berkeadilan. Inilah wujud dari sikap inklusif dari tokoh-kepala adat Dayak yang diwariskan kepada generasi berikutnya dalam membangun kehidupan dan menyelesaikan seluruh masalah di lingkungan keluarga, masyarakat, dan bangsa. Pendekatan ini telah mendorong kesadaran hidup dari setiap individu dan kelompok yang berbeda suku, etnis, budaya, dan agama demi

\footnotetext{
${ }^{30}$ Ahmadi Isa, "Karakteristik Rumah Betang dalam Perspektif Sosial Keagamaan," Himmah: Jurnal Ilmiah Keagamaan dan Kemasyarakatan 2, no. 6 (2004), 16.
} 
terciptanya kerukunan, kedamaian, serta terwujudnya pesatuan dan kesatuan yang saling menguatkan. ${ }^{31}$

Lebih lanjut Usop menyatakan bahwa salah satu bukti perubahan sosial dari semakin menguatnya pemahaman dan sikap yang berpegang teguh pada nilai budaya belom bahadat adalah: 1) masyarakat suku Dayak sangat menghotmati perbedaan-perbedaan nyata dalam kehidupan keluarga, masyarakat, dan bangsa; 2) lahirnya lembaga adat yang berfungsi sebagai lembaga perdamaian adat dan penyelesaian perkara yang terjadi antar masyarakat yang muncul pada masa orde baru, antara lain: Lembaga Musyawarah Masyarakat Dayak di daerah Kalimantan Tengah dan Kalimantan Barat, Persekutuan Dayak Kalimantan Timur, dan Lembaga Musyawarah Masyarakat Dayak Meratus di Kalimantan Selatan. ${ }^{32}$

Hal yang sama ditegaskan oleh Laksono bahwa nilai belom bahadat atau kehidupan yang menghargai tradisi, budaya, dan agama setiap manusia di manapun mereka berada telah membentuk cara pandang dan sikap masyarakat suku Dayak lebih inklusif dalam memahami perbedaan sosial, budaya, dan agama dalam kehidupan keluarga dan masyarakat. Mereka saling menghargai, saling silaturrahmi, dan saling melindungi antar sesama warga. Ini karena setiap kelompok yang berbeda suku, tradisi, budaya, dan agama berpegang teguh pada budaya belom bahadat.$^{33}$

Di Kalimantan Tengah, hubungan interaksi sosial antar suku dan umat beragama sangat harmonis. Pada umumnya mereka saling menghormati sehingga tidak terjadi konflik. Sikap toleransi mereka tampak ketika mereka saling mengunjungi apabila masing-masing merayakan hari raya keagamaan dan pelaksanaan upacara-upacara adat. Sikap saling menghormati tidak hanya dalam hal kebebasan melaksanakan ajaran agama, tetapi juga dalam hal jamuan makan dan

\footnotetext{
${ }^{31}$ KMA Usop, "Hubungan Kekerabatan Pada Masyarakat Kalimantan Tengah," Himmah: Jurnal Ilmiah Keagamaan dan Kemasyarakatan 2, no. 6 (2004), 14.

${ }^{32}$ Ibid., 31.

${ }^{33}$ P.M. Laksono, Pergulatan Identitas Dayak dan Indonesia Belajar dari Tjilik Riwut (Yogyakarta: Galang Press, 2006), 74.
} 
minuman yang disesuaikan dengan tradisi dan hukum menurut agama masing-masing. Sikap toleransi ini tumbuh dari prinsip mereka yang berpegang teguh pada nilai budaya belom bahadat atau menghargai adat, tradisi, budaya, dan agama setiap manusia yang diwariskan dari nenek moyang mereka melalui bimbingan kepala adat dalam keluarga betang, termasuk tradisi ungkapan ulub itah (orang kita) apapun agamanya. Uluh, menggambarkan ikatan persatuan kesukuan dan persaudaraan meskipun berbeda suku, agama, dan budaya. Perbedaan ini tidak meretakkan ikatan persaudaraan dan kesatuan mereka. Transmisi dan internalisasi nilai budaya belom bahadat melalui keluarga betang dalam kehidupan sehari-hari selama bertahun-tahun telah mewujudkan pola kehidupan suku Dayak memiliki cara pandang dan sikap lebih inklusif dalam memahami dan menerima perbedaan suku, tradisi, budaya, dan agama dalam kehidupan keluarga dan masyarakat. Mereka tidak mempersoalkan perbedaan agama, suku, ras, etnik, dan budaya. ${ }^{34}$

Contoh semakin kuatnya pemahaman nilai budaya belom babadat (menghargai adat, tradisi, budaya, dan sistem kepercayaan setiap manusia) dan bapakat (kekeluargaan, persaudaraan, solidaritas, dan gotong royong) yang dominan dalam kehidupan keluarga betang dan masyarakat misalnya dapat dilihat dari perubahan sosial mereka di dalam keluarga betang maupun dalam masyarakat. Jika salah satu anggota keluarga betang mengadakan upacara tiwah yang sangat sakral, yaitu penghormatan terhadap leluhur, semua pemeluk agama lain di rumah betang membantu kegiatan tersebut. Meskipun anak cucu mereka sudah berubah kepercayaan, tetapi rasa saling menghormati sangat tinggi, sehingga mereka rela untuk mengorbankan harta untuk mengadakan upacara pembongkaran makam leluhur, kemudian tulang belulangnya dibersihkan dan disimpan pada sebuah sandung yang mereka buat secara bergotong royong. Dengan berpegang teguh pada nilai budaya belom bahadat ini, mereka tidak pernah menolak kehadiran tamu dari mana saja untuk tinggal di rumah betang, selama tamu tersebut mengikuti nilai

${ }^{34}$ Wahidin Usop, "Hubungan Kekerabatan Masyarakat Kalimantan Tengah," Himah: Jurnal Ilmiah Agama dan Kemasyarakatan 2, no. 23 (2001), 11. 
budaya "di mana langit di junjung di situ bumi diinjak." Penuh toleran merupakan sikap dalam tradisi atau budaya kehidupan keluarga betang yang menunjukan sikap inklusif, saling menghargai dan menghormati aktivitas yang dilakukan orang lain. Pandangan dan sikap inklusif muncul pada masyarakat suku Dayak dalam lingkungan keluarga dan masyarakat yang berkembang di era modern ini, pada umumnya seperti perbedaan sistem kepercayaan antara anak dengan orang tua, kakak dan adik, atau mereka yang ada di sekitarnya pada saat masing-masing menunaikan ibadah keagamaan dan perayaan hari besar keagamaan, di mana mereka saling mendukung dalam suasana damai. Transmisi dan internalisasi pendekatan budaya belom bahadat yang sudah turun temurun, yaitu jika sekelompok warga akan melaksanakan upacara ritual keagamaan, maka bagi penganut agama atau kepercayaan lain membantu mempersiapkan berbagai bahan, berupa beras, ayam, minyak goreng, garam, dan lain-lain. Ini dimaksudkan agar para penganut kepercayaan yang berbeda turut merasakan segala suka cita mereka dalam kebersamaan. Namun, cara memasak dipersilakan untuk dimasak oleh kelompok itu sendiri. Sikap toleransi juga tidak memandang perbedaan kepercayaan yang dianut oleh warga yang tinggal dalam satu rumah. Di sini salah satu bentuk sikap inklusif yang berkembang dalam kehidupan keluaraga betang dan masyarakat suku Dayak Kalimantan Tengah. ${ }^{35}$

Menurut Isa, pendekatan budaya belom bahadat terbukti mampu mengikat emosi setiap komunitas yang berbeda identitas sosial, budaya, dan agama, di mana setiap manusia sebagai mahluk Tuhan memiliki derajat kemanusiaan yang sama. Hal ini ditegaskan dalam inti budaya belom bahadat. Nilai tersebut mengandung makna luhur yang menggambarkan persatuan dan kesatuan dalam kehidupan keluarga dan

\footnotetext{
${ }^{35}$ Noorsanie Darlan, "Implementasi Nilai-nilai Budaya Betang dalam Membina kerukunan Hidup" (Makalah disampaikan pada acara dialog Internasional tentang Budaya Dayak dan Melayu di Aula Universitas Negeri Palangka Raya, Palangka Raya, 1 November 2014), 11.
} 
masyarakat suku Dayak laksana satu rumah dengan jumlah penghuni yang berbeda suku, kulit, sifat, karakter, budaya, bahasa, dan agama. ${ }^{36}$

Searah dengan penjelasan di atas, Ahmad yang notabene sebagai Ketua Adat Dayak Kalimantan Tengah menjelaskan bahwa nilai budaya belom bahadat atau kehidupan yang menghargai adat, tradisi, budaya, dan sistem kepercayaan setiap manusia di manapun berada mengandung nilai kemanusiaan yang tinggi, yaitu manusia memiliki derajat yang sama. Meskipun setiap individu memiliki identitas yang berbeda tetapi dengan ikatan kemanusiaan sebagai kunci perekat yang menafikan unsur perbedaan bagi kehidupan sosial masyarakat Dayak dengan suku-suku lain. Dengan prinsip budaya belom bahadat, meskipun anggota keluarga betang tidak semua berasal dari satu suku, etnis, budaya, dan agama, tetapi dengan ikatan nilai budaya belom bahadat masyarakat suku Dayak pada umumnya memiliki sikap inklusif dalam memahami dan menerima seluruh perbedaan setiap individu dalam kehidupan keluarga, masyarakat, dan kehidupan bangsa. Mereka hidup rukun dan damai, karena telah diikat dengan nilai budaya belom babadat, suatu nilai universal yang menajadi misi kemanusiaan, sebuah tradisi atau budaya kehidupan dari para leluhur tokoh-kepala adat Dayak sebelumnya. ${ }^{37}$

Dalam kehidupan rumah tangga, kesetaraan dan kebersamaan terlihat jelas dalam peran laki-laki dan perempuan yang saling berbagi sesuai kemampuan dan kesepakatan. Pada akhirnya, emansipasi gender dalam budaya Dayak tidak diperdebatkan. Ini adalah perwujudan dari nilai budaya belom babadat atau kesetaraan (egaliter) dalam kehidupan keluarga betang dan masyarakat Dayak. Selian itu, juga dapat dilihat dari bahasa, di mana kata "anda dan kamu" dipakai untuk siapa saja. Ini menunjukan nilai kesetaraan menjadi ciri yang dominan dalam budaya kehidupan keluarga betang dan masyarakat Dayak. Kesetaraan antara sesama manusia diatur dalam budaya belom bahadat dan hukum adat.

\footnotetext{
${ }^{36}$ Ibid., 32.

${ }^{37}$ Sabran Ahmad, "Filosofi Huma Betang," dalam Falsafah Hidup Budaya Huma Betang dalam Membangun Kerukunan Hidup Umat Beragama di Palangka Raya, eds. Muhammad dan Abubakar (Malang: Aditya Media, 2010), 60.
} 
Hukum tersebut yang paling berpengaruh dan berperan penting dalam menjaga kelangsungan hubungan harmonis antara individu, alam, sang pencipta, dan masyarakat. Damang, sebagai kepala adat sangat berperan dalam merekatkan hubungan sesama warga yang berbeda suku, adat, tradisi, budaya, dan agama serta mengatasi konflik sosial yang diikat dengan prinsip hapakat basara atau musyawarah mufakat dan perdamaian atas dasar kemanusiaan. ${ }^{38}$

Bukti perubahan sosial lainya dari semakin menguatnya pemahaman dan sikap yang berpegang teguh pada nilai budaya belom bahadat juga tampak terjalinya persatuan dan kesatuan dalam hubungan interaksi sosial keagamaan antar individu dan kelompok yang berbeda suku, etnis, tradisi, budaya, dan agama dalam kehidupan keluarga Dayak. Hal ini dijelaskan Pendeta Umbing bahwa salah satu bukti perubahan sikap masyarakat Dayak yang berpegang teguh pada nilai budaya belom bahadat misalnya dalam satu keluarga suku Dayak banyak yang memiliki keyakinan yang berbeda-beda, ada Islam, Kristen Protestan, Katholik, dan Kaharingan. Perbedaan keyakinan dalam satu keluarga bagi suku Dayak tidak menjadi persoalan. Mereka tetap saling menghargai satu sama lain dalam menjalankan ibadah sesuai kepercayaan yang dianut. Perbedaan diikat dengan ikatan belom bahadat atau hidup yang menghargai adat, budaya, dan sistem kepercayaan setiap manusia. Oleh karena itu, dalam satu keluarga meskipun berbeda suku, ras, tradisi, budaya, dan agama dapat hidup harmonis dan damai. Dalam pengambilan keputusan dan penyelesaian masalah juga diselesaikan dengan bapakat atau musyawarah dan kekeluargaan. Di sini bentuk sikap inklusif dalam keluarga dan masyarakat suku Dayak. ${ }^{39}$

\footnotetext{
${ }^{38}$ Kusni Sulang, Budaya Dayak Permasalahan dan Alternatifnya: Berdiri Di Kampung Halaman Memandang Tanah Air Merangkul Dunia (Malang: Bayumedia, 2011), 231.

${ }^{39}$ Dimer Umbing, "Jalinan Persaudaraan dalam Keluarga Huma Betang," dalam Falsafah Hidup Budaya Huma Betang Dalam Membangun Kerukunan Hidup Umat Beragama di Kota Palangka Raya Kalimantan Tengah, eds. Muhammad dan Abubakar (Malang: Aditya Media Publishing, 2010), 76.
} 
Nilai budaya belom bahadat atau kehidupan yang menghargai adat, tradisi, budaya, dan agama setiap manusia di manapun berada merupakan landasan moral dan sosial telah mampu mencairkan keterasingan individu atas individu lain. Nilai budaya tersebut dipraktikan dalam bentuk relasi dan interaksi sosial dalam keluarga betang di bawah bimbingan kepala adat dan dalam kehidupan sosial masyarakat pada kenyataanya seluruh keluarga betang yang beragam suku, etnis, tradisi, budaya, dan agama. Mereka dapat bersatu dengan pihak lain yang memiliki sub kultur, sub etnik, dan sistem kepercayaan yang berbeda. Ikatan nilai budaya belom bahadat telah menciptakan persatuan, kekeluargaan, dan persaudaraan dalam kehidupan betang dan masyarakat serta terbentuknya sikap masyarakat suku Dayak lebih inklusif dalam menerima dan memperlakukan sesama manusia dengan baik, sebagai bagian dari keluarga dan komunitas suku Dayak. Masalah yang muncul akibat perbedaan pendapat diselesaikan dengan tradisi musyawarah mufakat dan kekeluargaan di bawah pengaturan kepala adat betang, yang diangkat langsung oleh masyarakat untuk menyelesaikan sengketa sosial dan mewariskan nilai adat dan budaya betang kepada generasi muda, penanggung jawab upacara adat, menata dan mengatur kehidupan warga betang, pemberi sanksi bagi anggota keluarga betang yang melanggar adat. ${ }^{40}$

${ }^{40} \mathrm{Ibid} ., 72$. 


\section{Penutup}

Model pengelolaan konsensus budaya belom bahadat telah membawa perubahan polarisasi kehidupan sosial dan keagamaan masyarakat Dayak, yaitu cara pandang dan sikap inklusif dalam memahami dan menerima perbedaan sosial, tradisi, budaya, dan agama dalam kehidupan keluarga, masyarakat, dan berbangsa. Perubahan ini memperkuat integrasi sosial antar individu dan kelompok yang berbeda suku, etnis, budaya, dan agama dalam kehidupan keluarga, masyarakat, dan bangsa serta mencegah tumbuhnya radikalisme dan terorisme yang muncul dari kalangan tokoh-tokoh keagamaan, budayawan, dan tokoh masyarakat di era modernisasi ini. Prosesnya melalui: 1) legitimasi konsensus tokoh adat dan pemerintah daerah dalam memberlakukan nilai budaya belom bahadat sebagai prinsip dasar kehidupan masyarakat Dayak; 2) legitimasi konsensus budaya belom bahadat menjadi landasan pemerintah daerah, tokoh-tokoh adat, dan tokoh agama-agama dalam membina persatuan dalam kehidupan sosial, budaya, agama, dan bangsa; 3) transmisi dan internalisasi budaya belom bahadat setiap kelompok etnis, budaya, dan agama dalam institusi keluarga betang; 4) legitimasi pemberlakukan budaya belom bahadat sebagai prinsip kesetaraan kehidupan sosial, gender, budaya, dan agama dalam keluarga betang, msyarakat, dan bangsa; 5) legitimasi konsensus budaya belom bahadat sebagai landasan kebijakan pengembangan lembaga pendidikan, pusat kajian sosial, seni budaya, agama, dan tempat peribadatan setiap kelompok agama dan budaya secara adil; 6) pelembagaan budaya belom bahadat melalui lembaga musyawarah adat untuk menyelesaikan konflik sosial dan keagamaan dengan prinsip hapakat basara atau musyawarah mufakat, kekelurgaan, dan perdamaian. 


\section{Daftar Pustaka}

Ahmad, Sabran. "Filosofi Huma Betang." Dalam Falsafah Hidup Budaya Huma Betang dalam Membangun Kerukunan Hidup Umat Beragama di Palangka Raya, eds. Muhammad dan Abubakar. Malang: Aditya Media, 2010.

Alfon, Paulus. "Kedudukan Laki-laki dan Perempuan dalam Keluarga Betang." Dalam Falsafah Hidup Budaya Huma Betang dalam Membangun Kerukunan Hidupn Umat Beragama di Kota Palangka Raya, eds. Muhammad dan Abubakar. Malang: Aditya Media, 2010.

BPS Provinsi Kalimantan Tengah. Penduduk Kalimantan Tengah Tahun 2016. Palangka Raya: BPS, 2016.

Darlan, Noorsanie. "Implementasi Nilai-nilai Budaya Betang dalam Membina kerukunan Hidup." Makalah disampaikan pada acara dialog Internasional tentang Budaya Dayak dan Melayu di Aula Universitas Negeri Palangka Raya, Palangka Raya, 1 November 2014.

Davis, Kingsley. Human Society. New York: Mc Graw-Hill, 1948.

Ilon, Y. Nathan. Filsafat Huma Betang Suku Dayak Ngaju Kalimantan Tengah. Palangka Raya: PT. Sinar Bagawan Khatulistiwa, 1997.

Iper, Dunis. Kosa Kata Babasa Dayak Ngaju-Indonesia. Palangka Raya: PT Bengawan Khatulistiwa, 2009.

Isa, Ahmadi. "Karakteristik Rumah Betang dalam Perspektif Sosial Keagamaan." Himmab: Jurnal Ilmiah Keagamaan dan Kemasyarakatan 2, no.6 (2004).

KDR, Lewis. "Interaksi Sosial dalam Keluarga Betang." Dalam Falsafah Hidup Budaya Huma Betang dalam Membangun Kerukunan Hidup Umat Beragama di Kota Palangka Raya, eds. Muhammad dan Abubakar. Malang: Aditya Media, 2010.

Laksono, P.M. Pergulatan Identitas Dayak dan Indonesia Belajar dari Tjilik Riwnt. Yogyakarta: Galang Press, 2006.

Maunati, Yekti. Identitas Dayak: Komodifikasi dan Politik Kebudayaan. Yogyakarta: Lkis, 2004.

Metton, Robert K. Social Structure and Science. Chicago: The University of Chicago Press, 1994. 
Muhammad. Falsafah Hidup Budaya Huma Betang dan Integrasi Sosial di Kalimantan Tengah. Malang: Aditya Media, 2014.

Riwut, Nilai. Kalimantan Membangun Alam dan Kebudayaan. Solo: NR Publishing, 2007.

Siyok, Demianus dan Tiwi. Etika Mutiara Isen Mulang: Memahami Bumi dan Manusia. Palangka Raya: PT. Sinar Bagawan Khatulistiwa, 2014.

Soemardjan, Selo. Setangkai Bunga Sosiologi. Jakarta: Universitas Indonesia Press, 1974.

Sulang, Kusni. Budaya Dayak Permasalahan dan Alternatifnya: Berdiri di Kampung Halaman Memandang Tanah Air Merangkul Dunia. Malang: Bayumedia, 2011.

Umbing, Dimer. "Jalinan Persaudaraan dalam Keluarga Huma Betang." Dalam Falsafah Hidup Budaya Huma Betang Dalam Membangun Kerukunan Hidup Umat Beragama di Kota Palangka Raya Kalimantan Tengah, eds. Muhammad dan Abubakar. Malang: Aditya Media Publishing, 2010.

Usop, Abdurrahman Sidik. Sejarah Kabupaten Kapuas. Palangka Raya: PT. Sinar Bagawan Khatulistiwa, 1994.

Usop, KMA. "Sistem Religi Masyarakat Dayak." Himmah: Jurnal Ilmiah Keagamaan dan Kemasyarakatan 2, no. 23 (2001).

"Hubungan Kekerabatan Pada Masyarakat Kalimantan Tengah." Himmab: Jurnal Ilmiah Keagamaan dan Kemasyarakatan 2, no. 6 (2004).

Usop, Sidik Rahman. "Akulturasi Nilai-nilai Keislaman dan Budaya Dayak." Himmah: Jurnal Keagaman dan Kemasyarakatan 1, no. 2 (2016).

Usop, Wahidin. "Hubungan Kekerabatan Masyarakat Kalimantan Tengah." Himah: Jurnal Ilmiah Agama dan Kemasyarakatan 2, no. 23 (2001). . "Memahami Budaya Betang dalam Perspektif Integrasi social." Makalah disampaikan pada acara dialog Internasional di Aula Universitas Negeri Palangka Raya tentang Budaya Dayak dan Melayu, Palangka Raya, 1 November 2014. 